Jurnal Tabarru' : Islamic Banking and Finance

Volume 4 Nomor 1, Mei 2021

p-ISSN 2621-6833

e-ISSN 2621-7465

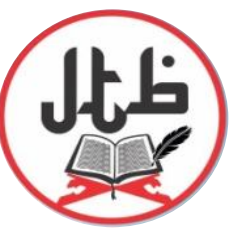

\title{
PEMBIAYAAN MURABAHAH DI PT. FEDERAL INTERNATIONAL FINANCE SYARIAH PEKANBARU
}

\author{
Rio Ependi ${ }^{1}$ \& Husni Thamrin ${ }^{2}$ \\ ${ }^{1 \& 2}$ Program Studi Ekonomi Syariah, Pascasarjana UIN Suska Riau \\ Email :rioefendy29@gmail.com, husni2017husni@gmail.com
}

\begin{abstract}
ABSTRAK
Faktor penting yang melatar belakangi lahirnya bank syariah maupun lembaga keuangan mikro syariah adalah pelarangan riba secara tegas dalam Alquran. Murabahah adalah suatu jenis pembiayaan dimana perjanjian pembiayaan dilaksanakan dengan menyatakan harga pokok barang dan margin keuntungan yang disepakati oleh penjual dan pembeli. Perusahaan pembiayaan FIF Syariah sebagai salah satu bentuk perusahaan pembiayaan yang berbasis syariah bukan bank menjadi salah satu alternatif dari metode pembiayaan yang lebih fleksibel dalam menyalurkan dana berupa pembiayaan secara syariah kepada masyarakat diIndonesia. Penelitian ini akan membahas tentang akad murabahah pada FIF Syariah, bagaimana konsep pembiayaan FIF Syariah serta pembiayaan murabahah yang ada di FIF Syariah.
\end{abstract}

Kata Kunci: Murabahah, Pembiayaan, FIF Syariah.

\begin{abstract}
An important factor behind the birth of Islamic banks and Islamic microfinance institutions is the strict prohibition of usury in Al-Quran. Murabahah is a type of financing in which the financing agreement is executed by stating the cost of goods and the profit margin agreed upon by the seller and the buyer. FIF Syariah financing company as a form of non-bank sharia-based financing company is an alternative to a more flexible financing method in channeling funds in the form of sharia financing to the people of Indonesia. This research will discuss about the murabahah contract in FIF Syariah, how the concept of FIF Syariah financing and murabahah financing in FIF Syariah.
\end{abstract}

Keyword : Murabahah, Financing, FIF Syariah. 


\section{PENDAHULUAN}

Perkembangan ekonomi Islam di Indonesia cukup pesat. Hal itu ditandai dengan meningkatnya jumlah bank syariah dan lembaga keuangan non bank. Ada beberapa yang memang asli syariah, akan tetapi ada yang berupa unit usaha syariah. Dalam kehidupan perekonomian, kita tidak hanya mengenal perbankan syariah yang memang menjadi perhatian banyak orang. Ekonomi Islam bukan hanya sekedar membahas tentang perbankan Islam, tetapi semua hal yang berkaitan dengan kehidupan ekonomi manusia (Muhaimin, 2012).

Perkembangan perbankan dengan menggunakan prinsip syariah atau lebih dikenal dengan nama bank syariah ataupun lembaga keuangan mikro syariah (LKMS) di Indonesia, bukan merupakan hal yang asing lagi. Namun sejak tahun 1992, telah muncul lembaga keuangan yang berbasis syariah yang melarang praktek konsep bunga (riba) pada operasional mereka. Faktor penting yang melatar belakangi lahirnya bank syariah maupun lembaga keuangan mikro syariah adalah pelarangan riba secara tegas dalam Alquran. Riba adalah pengambilan tambahan, baik dalam transaksi jual beli maupun pinjam meminjam secara batil atau bertentangan dengan prinsip muamalah dalam Islam.

Perluasan lembaga pembiayaan disambut baik oleh pemerintah, yaitu dengan adanya Kepres No. 61 Tahun 1988, dimana dalam Kepres ini di dalamnya terdapat landasan operasional yang jelas. Adapun beberapa jenis usaha dalam lembaga pembiayaan diantaranya adalah sewa guna usaha (leasing), modal ventura (venture capital), kartu plastik, anjak piutang, (factoring), pembiayaan konsumen (consumers finance), dan perdagangan surat berharga (Handiman, 2006). Melihat karakteristik jenis usaha yang beragam, maka perusahaan pembiayaan yang melakukan lebih dari satu kegiatan sering disebut dengan multifinance company (Soemitra, 2009).

Dalam perkembangan selanjutnya, landasan hukum perusahaan pembiayaan semakin kuat dengan Peraturan Menteri Keuangan Nomor 84/PMK.012/2006 tentang perusahaan pembiayaan, yang menjelaskan bahwa : "Perusahaan pembiayaan adalah badan usaha di luar bank dan lembaga keuangan bukan bank yang khusus didirikan untuk melakukan kegiatan yang termasuk dalam bidang usaha lembaga pembiayaan". Peraturan Menteri Keuangan inilah yang membuat posisi lembaga pembiayaan memiliki peluang yang besar dalam mengembangkan dan menguatkan lembaga pembiayaan di Indonesia. Secara umum perusahaan pembiayaan berfungsi menyediakan produk yang berkualitas dan pelayanan yang profesional. Selain beroperasi menggunakan system keuangan konvensional, lembaga pembiayaan ini juga dapat melakukan kegiatannya dengan pembiayaan berdasarkan prinsip syariah dimana pada saat ini prinsip syariah sedang berkembang dalam berbagai transaksi keuangan di Indonesia sebagai alternatif pembiayaan yang adil dan berkah bagi individu yang menjalankannya (Sunaryo, 2013).

Dalam pelaksanaan kegiatan
pembiayaan konsumen perusahaan
pembiayaan dalam hal ini FIF Syariah
Pekanbaru apakah telah melakukan akad
sesuai dengan prinsip syariah. Terkait
dengan perkembangan pembiayaan FIF
Syariah Pekanbaru tidak lupa pula dalam
penerapan prinsip Syariah pada pembiayaan
konsumen harus ditunjang dengan


penerapan asas kesetaraan dan keseimbangan para pihak, terutama dalam menentukan hak dan kewajiban para pihak dalam melaksanakan akad Murabahah. Penerapan asas persamaan dan kesetaraan pada akad Murabahah bertujuan untuk menjamin segala hak dan kewajiban para pihak baik dalam menentukan klausul akad, dalam pelaksanaan akad, dan hak kewajiban para pihak apabila terjadi perselisihan antara kedua belah pihak (Ega, 2005).

Menurut Fatwa Dewan Syariah Nasional MUI No. 04/DSN-MUI/IV/2000 tentang murabahah disebutkan bahwa PT. FIF Syariah harus membeli terlebih dahulu aset yang dipesan oleh nasabah secara sah dan kemudian menawarkan aset tersebut kepada nasabah. Syarat-syarat benda yang menjadi objek akad dalam akad murabahah, barang yang diperjual belikan secara prinsip harus sudah menjadi milik PT. FIF Syariah. Tidak sah menjual barangbarang yang baru akan menjadi miliknya.

\section{TINJAUAN PUSTAKA}

\section{Konsep Murabahah}

Menurut Antonio (2003) dalam bukunya mengartikan bahwa Murabahah adalah jual beli barang pada harga asal dengan tambahan keuntungan yang disepakati. Dalam hal ini, penjual harus memberikan pokok produk yang ia beli dan menentukan suatu tingkat keuntungan sebagai tambahan, menentukan lama pembiayaan dan besar angsuran yang akan diangsur.

Murabahah didefinisikan oleh para Fuqaha sebagai penjualan barang seharga biaya/harga pokok (cost) barang tersebut ditambah mark-up atau margin keuntungan yang disepakati. Murabahah adalah jual beli barang pada harga asal dengan tambahan keuntungan yang disepakati. Karakteristik murabahah adalah penjual harus memberi tahu harga yang ia beli dan menentukan suatu tingkat keuntungan sebagai tambahannya.

Murabahah merupakan salah satu produk penyaluran dana di FIF Syariah karena karakternya yang profitable, mudah dalam penerapan, FIF Syariah bertindak sebagai pembeli sekaligus penjual barang halal tertentu yang dibutuhkan nasabah. Mula-mula FIF Syariah membeli barang sebagaimana dimaksud kepada pihak ketiga dengan harga tertentu, secara langsung atau melalui wakil yang ditunjuk, untuk selanjutnya barang tersebut dijual kepada nasabah dengan harga tertentu setelah ditambah keuntungan (mark-up) yang disepakati bersama (Wiroso, 2005).

Murabahah merupakan kontrak jual-beli dimana bank bertindak sebagai penjual sementara nasabah sebagai pembeli. Harga jual adalah harga beli bank ditambah keuntungan. Walaupun akad murabahah ini sering digunakan, namun sebagian masyarakat belum mengerti tentang implementasi akad ini. Sehingga banyak anggapan bahwa praktik pada lembaga keuangan syariah tidak berbeda jauh dengan lembaga keuangan konvensional yang terlebih dahulu dikenal oleh masyarakat luas (Melina dan Zulfa, 2020).

Sedangkan menurut Haitam dalam Haryoso (2017) murabahah adalah sebuah pergeseran kepemilikan sesuatu yang dimiliki yang kemudian dijual dengan harga pertama lalu diberikan sedikit tambahan keuntungan. Dari beberapa definisi di atas pada dasarnya sama, yakni murabahah merupakan kegiatan jual beli dimana penjual memberi tahukan atau menceritakan biaya perolehan barang yang sesungguhnya 
kepada konsumen lalu ditambahkan keuntungan atas penjualan barang tersebut berdasarkan biaya yang dikeluarkan dan kesepakatan antara penjual dan pembeli.

\section{Landasan Hukum Pembiayaan Murabahah}

Murabahah merupakan bagian terpenting dari jual beli dan prinsip ini mendominasi pendapatan bank dari produkproduk yang ada di semua bank Islam serta lembaga keuangan syariah lainnya. Dalam Islam, jual beli sebagai sarana tolong menolong antara sesama umat manusia yang diridhai oleh Allah SWT.

Firman Allah SWT dalam QS. Al-Baqarah ayat 275 :

Artinya:"Dan Allah SWT telah menghalalkan jual beli dan mengharamkan riba."

Firman Allah SWT dalam QS. Al-Maidah ayat 1 :

Artinya:"Hai orang-orang yang beriman, penuhilah akad-akad itu."

Firman AllahSWT dalam QS. An-Nisa ayat 29

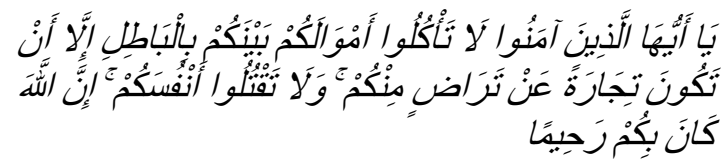

Artinya :"Hai orang-orang yang beriman, janganlah kamu saling memakan harta sesamamu dengan jalan yang batil, kecuali dengan jalan perniagaan yang berlaku dengan suka sama-suka di antara kamu. Dan janganlah kamu membunuh dirimu; sesungguhnya Allah SWT adalah Maha Penyayang kepadamu."

Dalam surat An-Nisa ayat 29 merupakan larangan tegas mengenai memakan harta orang lain dengan jalan bathil, kecuali dengan jalan perniagaan yang berlaku atas suka sama suka. Memakan dengan cara yang bathil maksudnya adalah memakannya dengan jalan riba, judi, menipu, menganiaya dan hal-hal yang dilarang Allah SWT. Akan tetapi diperbolehkan bagi kalian untuk mengambil harta milik selainmu dengan cara dagang yang lahir dari keridhaan dan keikhlasan hati antara dua pihak (atas suka sama suka), dalam jual beli diperbolehkan kita untuk mengambil keuntungan dari barang yang diperjual belikan sesuai dengan akad diawal.

Hadis Nabi riwayat Tirmidzi Artinya :"Perdamaian dapat dilakukan di antara kaum Muslimin kecuali perdamaian yang mengharamkan yang halal atau menghalalkan yang haram; dan kaum Muslimin terikat dengan syarat-syarat mereka kecuali syarat yang mengharamkan yang halal atau menghalalkan yang haram." (HR. Tirmizi dari Amr bin Auf).

\section{Ketentuan Murabahah}

Ketentuan murabahah diatur pula dalam Fatwa DSN No.04/SDSNMUI/IV/2000 yaitu:

a) Bank dan nasabah harus melakukan akad murabahah yang bebas riba.

b) Barang yang dijual belikan tidak diharamkan oleh syariat Islam.

c) Bank membiayai sebagian atau keseluruhan harga pembelian barang yang telah disepakati kualifikasinya.

d) Bank membeli barang yang diperlukan nasabah atas nama bank sendiri, dan pembeli ini harus sah dan bebas riba.

e) Bank harus menyampaikan semua hal yang berkaitan dengan pembelian, misalnya jika pembelian barang dilakukan secara utang. Bank kemudian menjual barang tersebut 
kepada nasabah dengan harga senilai harga plus keuntungannya. Dalam kaitan ini bank harus memberitahu secara jujur harga pokok barang kepada nasabah berikut biaya yang diperlukan.

f) Nasabah membayar harga barang pada jangka waktu tertentu yang telah disepakati.

g) Untuk mencegah terjadinya penyalahgunaan atau kerusakan akad pihak bank dapat mengadakan perjanjian khusus dengan nasabah.

h) Jika bank hendak mewakilkan kepada nasabah untuk membeli barang dari pihak ketiga, akad jualbeli murabahah harus dilakukan setelah barang secara prinsip menjadi milik bank (Wiroso, 2005).

\section{METODE PENELITIAN}

Metode penelitian ini adalah jenis penelitian lapangan (field research) yang dilakukan di FIF Syariah Pekanbaru. Pengumpulan data menggunakan metode observasi dan mencari data-data yang diperlukan dari obyek penelitian yang sebenarnya. Setelah mendapatkan data yang diperlukan, maka data tersebut dianalisis dengan metode deskriptif analisis dengan mendeskripsikan bagaimana fakta yang terjadi di FIF Syariah pekanbaru dan analisis kasus tersebut dalam perspektif hukum Islam.

\section{HASIL DAN PEMBAHASAN}

FIF syariah dibentuk oleh Astra Group yang mana sebelumnya ditangani oleh PT AMF (Astra Multi Finance), namun seiring berjalannya waktu FIF mengambil alih perusahaan sehingga masuk dalam PT. FIF. Dari tahun 2005 hingga tahun 2009 FIF mampu mencakup 165 cabang diseluruh Indonesia, dan perusahaan ini hanya menjual produk Honda saja dalam pembiayaan motor karena Honda masih satu anak perusahaan PT. Astra Tbk.

Sementara itu FIF Syariah mulai diterapkan oleh PT. FIF Group Cabang Pekanbaru sejak tahun 2010. Mengenai produk pada FIF Sejauh ini produk pembiayaan motor syariah pada dasarnya adalah sama jenisnya dengan produk konvensional dan yang membedakan hanya terletak pada moralitas dan penerapan akadnya. Akad yang digunakan dalam pembiayaan syariah menggunakan murabahah atau dengan cara dicicil.

Proses pengajuan pembiayaan murabahah sebagai berikut:

a) Nasabah datang ke FIF untuk mengajukan pembiayaan sepeda motor dengan membawa beberapa persyaratan sebagai berikut:

- Nasabah membawa identitas diri asli dan foto copy KTP suami istri.

- Nasabah membawa Kartu Keluarga, rekening listrik.

- Nasabah membawa slip gaji pegawai

b) Kemudian pihak FIF melakukan survey, setelah proses pensurveian kemudian pihak FIF berhak menentukan apakah pengajuan pembiayaan itu di terima atau ditolak.

c) Setelah pengajuan pembiayaan itu di setujui oleh pihak FIF kemudian pihak FIF mengeluarkan unit sepeda motor.

d) Unit motor yang diperjual belikan, dikuasakan kepada debitur untuk membeli sendiri ke dealer kemudian nota pembeliannya diberikan kepada FIF Syariah. 


\section{Gambar 1. Skema pembiayaan pada FIF Syariah}

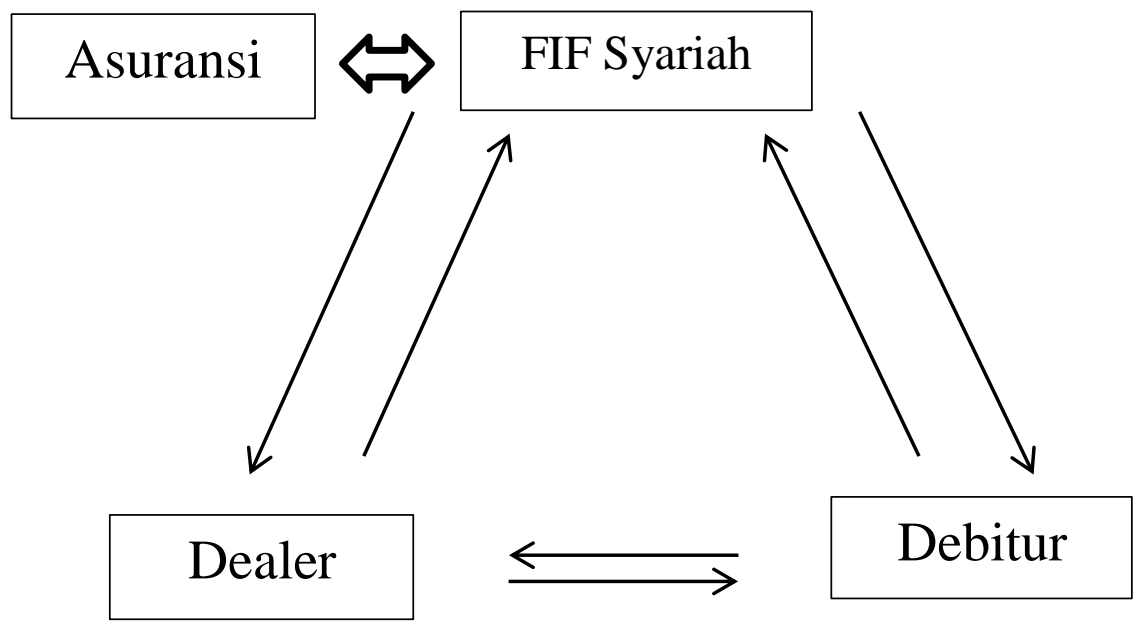

Hasil penelitian yang dilakukan merupakan penelitian lapangan, oleh sebab itu data yang disajikan dalam bab ini adalah data yang dikumpulkan dari lapangan. Adapun teknik pengumpulan data yang digunakan untuk memperoleh data tersebut adalah dengan menggunakan observasi, wawancara dan dokumentasi. Wawancara ini dilakukan dengan Pimpinan PT. FIF Syariah Kota Pekanbaru, dan 1 orang karyawan/I PT. FIF Syariah bagian Pembiayaan di PT. FIF Kota Pekanbaru. Kemudian data disajikan dalam bentuk uraian singkat kedalam masing-masing kategori dan disimpulkan secara kualitatif. Adapun penyajian dari hasil pengumpulan data berdasarkan beberapa dimensi dalam penelitian ini yang dijabarkan sebagai berikut:

\section{Objek Murabahah}

Obyek murabahah adalah perjanjian jual-beli antara PT. FIF Syariah dengan Nasabah. PT. FIF Syariah membeli barang yang diperlukan nasabah kemudian menjualnya kepada nasabah yang bersangkutan sebesar harga perolehan ditambah dengan margin keuntungan yang disepakati antara PT. FIF Syariah dan Nasabah (Iltiham, 2017).

Adapun akad yang digunakan pada FIF Syariah adalah akad murabahah. Akad murabahah adalah akad jual beli atas barang tertentu dimana penjual menyebutkan dengan jelas barang yang diperjualbelikan kepada pembeli termasuk harga pembelian dan keuntungan yang diambil.

Penjabaran dan implementasi akad murabahah yang berlaku pada FIF Syariah Pekanbaru adalah sebagai berikut:

1. Akad murabahah merupakan akad kesepakatan yang didasarkan atas suka sama suka (suka rela)

2. Akad murabahah adalah akad jual beli dan bebas dari unsur riba

3. Barang yang diperjual-belikan adalah barang yang tidak diharamkan oleh syariat Islam.

4. Harga penjualan adalah gabungan antara harga modal ditambah margin keuntungan. 
5. Masa pembayaran sesuai jangka waktu tertentu.

6. Diperbolehkan membayar uang muka atau uang panjar atau urbun.

7. Penalti atas keterlambatan pembayaran akan dikenakan denda, dan uangnya dijadikan dana sosial sebesar Rp. 5.000,- dari jumlah angsuran yang terlambat dan tidak boleh dinego atau dihapuskan.

Secara lengkap perjanjian akad murabahah yang diberlakukan pada FIF Syariah tertuang dalam Surat Pernyataan Konsumen yang garis-garis besar isinya adalah sebagai berikut:

Pihak pertama dan pihak kedua (secara bersama-sama selanjutnya disebut para pihak) tersebut menerangkan terlebih dahulu hal-hal berikut:

- Pembiayaan murabahah adalah penyediaan pembiayaan dalam rangka penyediaan barang secara syariah.

- Pemberi jaminan adalah orang atau badan yang memberikan jaminan pelunasan kewajiban pihak kedua.

- Dealer adalah orang atau badan yang melakukan kegiatan di bidang penyediaan barang.

○ Pembiayaan murabahah:

Pasal 1: Pihak pertama setuju untuk menyediakan pembiayaan murabahah dengan jaminan hak milik secara fidusia atas barang jaminan kepada pihak kedua guna pengadaan barang berupa Sepeda motor dengan spesifikasi yaitu meliputi Merk, Nomor Mesin, Tahun, Warna, Nomor BPKB dan lain-lain.

Pasal 2: Margin Keuntungan dan Total Kewajiban
1. Atas permohonan pihak kedua, pihak pertama dengan ini mengadakan barang dan pihak kedua menyatakan telah menerima barang dengan baik. Atas pengadaan barang tersebut, perjanjian ini berlaku sebagai tanda bukti penerimaan barang yang sah.

2. Pihak kedua atas pembiayaan ini sepakat mengikatkan diri untuk membayar pokok pembiayaan dan margin keuntungan dan biaya-biaya lainnya sesuai dengan kesepakatan bersama.

Dalam operasionalnya di PT. FIF Syariah Pekanbaru akad yang digunakan Juga adalah Murabahah. Meskipun akad yang digunakan adalah berdasarkan akad syariah, tetapi dari penerapan prinsip syariahnya masih belum sesuai dengan prinsip syariah yang sebenarnya. Karena dilihat dari praktik sehari-hari tidak ada yang membedakan antara syariah dan konvensional. Contohnya dalam penetapan bunga pada konvensional, di dalam pembiayaan syariahpun menetapkan bunga (Bagi hasil). Cuma bedanya pada saat konsumen (Costumer) melakukan pelunasan dimuka tidak dikenakan biaya Administrasi.

\section{Harga Perolehan dan Keuntungan}

Harga perolehan adalah seluruh biaya yang dikeluarkan untuk memperoleh aset tetap tersebut mulai dari biaya pembelian hingga semua biaya yang timbul hingga aset tetap tersebut siap digunakan atau dioperasikan (Maesaroh, 2017), sedangkan keuntungan adalah suatu modal atau laba yang diperoleh dari investasi dalam surat berharga atau efek, seperti saham, obligasi atau dalam bidang properti dimana nilainya melebihi harga pembelian (Haryoso, 2017). 
Dalam hal ini PT. FIF Syariah dan konvensional tidak terdapat perbedaan dalam menentukan laba, karena PT. FIF menghindari terjadinya persaingan antar cabang ataupun dealer baik itu syariah ataupun konvensional. Dalam menentukan margin PT. FIF selalu mengikuti terhadap pembiayaan yang dikeluarkan bank-bank yang melakukan join financing, jadi dalam penentuan laba PT. FIF masih bergantung pada bank yang bekerjasama dengan PT. FIF. Seperti yang kita lihat, tidak terdapat perbedaan harga antara pembiayaan motor syariah dengan konvensional mengenai angsuran perbulannya, perbedaan dalam menentukan margin antara PT. FIF Syariah dan konvensional, yaitu terletak pada penentuan keuntungan berdasarkan waktu.

\section{Uang Muka}

Uang muka adalah jumlah yang dibayar oleh pembeli kepada penjual sebagai bukti komitmen untuk membeli barang dari penjual atau pembayaran uang kepada pihak lain yang belum memberikan prestasi atau memenuhi kewajiban, misalnya kepada PT. FIF Syariah pada saat kontrak ditandatangani atau kepada penjual yang belum menyerahkan barangnya, pembayaran sebagian dan harga yang telah disepakati oleh pembeli dan penjual yang merupakan tanda bahwa perjajian jual beli yang diadakan mengikat.

Dari hasil observasi penulis menunjukkan bahwa hasil wawancara tersebut sesuai dengan kondisi yang ada dilapangan yang menjelaskan bahwa uang muka ditentukan sesuai permintaan nasabah/masyarakat dimana sesuai dengan barang yang dibeli, dan yang terpenting DP tersebut hanya diharuskan lebih dari $10 \%$ dari total harga pembiayaan.

Berdasarkan temuan diatas penulis berkesimpulan bahwa PT. FIF Syariah Kota
Pekanbaru menentukan uang muka produk pembiayaan murabahah sesuai dengan permintaan nasabah sesudah melakukan akad, serta jika terjadi pembatalan pembelian barang maka pihak nasabah harus menggati rugi, dan uang muka tersebut tidak dianggap sebagai uang ganti rugi, dan uang muka yang telah di berikan nasabah kepada PT. FIF Syariah akan di kembalikan.

Hasil analisis dan kesimpulan ini sejalan dengan penelitian sebelumnya oleh Melina (2020) mengenai uang muka produk pembiayaan murabahah, dimana uang muka ditentukan oleh nasabah pada saat melakukan akad bersama antara pengelolah dengan pembeli. Oleh karena itu PT. FIF Syariah tidak menentukan uang muka sendiri melainkan sesuai dengan harga barang yang dibeli.

Akan tetapi masih ada kekurangan yang harus diperhatikan PT. FIF Syariah kota pekanbaru dimana seharusnya uang muka disetor kedalam rekening nasabah, baru setelah proses akad selesai dilakukan, uang muka tersebut dipotong sebagai biaya angsuran awal dan biaya asuransi, hal ini dilakukan agar proses pembiayaan murabahah sesuai dengan konsep fiqh dan memenuhi syarat pokok murabahah.

Terkait dengan Asuransi syariah produk asuransi yang digunakan adalah akad dengan niat tabarru' (takaful) yaitu suatu niat tolong menolong sesama peserta apabila ada yang ditakdirkan mendapat musibah. Pada akhir periode asuransi, jika perusahaan asuransi memperoleh laba dan konsumen tidak pernah mengajukan klaim, maka konsumen yang bersangkutan berhak atas nisbah (hadiah/bonus) dengan jumlah tertentu sesuai tingkat investasi tahun tersebut. Apabila nisbah yang menjadi hak konsumen tidak diambil dalam jangka 
waktu yang disepakati maka akan diserahkan sebagai dana sosial. Apabila pada waktunya konsumen tidak dapat/lalai melakukan kewajibannya yaitu berupa pembayaran asuransi maka akan dikenakan penalty. Dalam hal konvensional, maka konsumen akan dikenakan bunga yang besarnya telah ditentukan.

\section{Pembelian dan Penyerahan Barang}

Pembelian merupakan kegiatan utama untuk menjamin kelancaran transaksi penjualan yang terjadi dalam suatu perusahaan atau pembelian merupakan bagian dari kegiatan ekonomi yang kita lakukan setiap hari dan penyerahan barang merupakan suatu kesepakatan antara penjual dengan pembeli tentang pemindahan hak milik disertai biaya pengiriman barang dari gudang penjual ke gudang pembeli (Suryani \& Afriyeni, 2019).

Dari hasil observasi penulis menunjukkan bahwa hasil wawancara tersebut sesuai dengan kondisi yang ada dilapangan yang menjelaskan bahwa pelaksanaan pembelian dan penyerahan barang disesuaikan dengan kebutuhan nasabah, dimana pembelian barang dilakukan oleh pihak PT. FIF Syariah, kemudian barang tersebut akan diserakan kepada nasabah saat menandatangani akad. Pembelian dan penyerahan barang merupakan suatu kesepakatan antara penjual dengan pembeli tentang pemindahan hak milik disertai biaya pengiriman barang dari gudang penjual ke gudang pembeli.

Berdasarkan temuan diatas penulis berkesimpulan bahwa PT. FIF Syariah Kota Pekanbaru menerapkan Pembelian dan Penyerahan Barang produk pembiayaan murabahah sesuai dengan permintaan nasabah sesudah melakukan akad, setelah itu pihak PT. FIF Syariah menyerahkan barang tersebut kepada nasabah. Hal ini sejalan dengan penelitian yang dilakukan oleh Melina (2020) mengenai proses pembelian dan penyerahan barang pada BMT dalam journal of Economic, Business and Accounting berjudul Implementasi pembiayaan Murabahah Pada Baitul Mal Wat Tamwil (BMT) Kota Pekanbaru.

Akan tetapi dalam pembelian dan penyerahan barang masih ada terdapat kekurangan yang harus diperhatikan PT. FIF Syariah pekanbaru, agar proses pembelian barang terlebih dahulu diselesaikan antara PT. FIF Syariah dengan supplier, baru setelah barang menjadi hak milik PT. FIF Syariah, barang tersebut dapat diperjual belikan dan diserahkan kepada nasabah setelah proses akad selesai dilakukan. Hal ini dilakukan agar proses pembiayaan murabahah sesuai dengan konsep fiqh dan memenuhi syarat pokok murabahah.

\section{Bentuk Penyelesaian Sengketa Para Pihak Apabila Salah Satu Pihak Melakukan Wanprestasi}

Dalam suatu perjanjian kredit, maupun dalam perjanjian-perjanjian lainnya, biasanya selalu dirincikan beberapa hal yang apabila dilakukan oleh salah satu pihak, maka terjadilah wanprestasi dan menyebabkan pihak lain dapat memutuskan perjanjian tersebut. Hal-hal atau kejadiankejadian sepert ini sering disebut dengan istilah "events of Default". Banyak hal apabila dilakukan oleh pihak debitur, maka debitur dapat dianggap dalam keadaan default (wanprestasi).

\section{Penyelesaian Sengketa Dalam Perjanjian Pembiayaan Konsumen (Consumer Finance)}


Keberadaan lembaga pembiayaan konsumen di Indonesia yang belum mempunyai aturan secara umum dalam Undang-Undang Dasar Republik Indonesia, sering memunculkan permasalahan dalam proses perjajian pembiayaan konsumen, para pihak mengaku mengalami kesulitan dalam menentukan dasar hukum apa yang akan digunakan dalam menyelesaikan masalah sengketa yang terjadi (Suherman, 2004).

Bedasarkan hasil wawancara dengan Bapak Ricky Wahyu Candra (Kepala Kredit Pembiayaan) bahwa penyelesaian sengketa pembiayaan syariah yang ditempuh oleh pihak PT. FIF Syariah cabang Pekanbaru jika salah satu pihak wanprestasi, misalnya terjadi kredit macet pembiayaan sepedamotor, maka sengketa ini diselesaikan secara musyawarah dengan menunjukkan bukti BSTBJ (Bukti Serah Terima Barang Jaminan dan Persetujuan). Jika konsumen tetap tidak mau membayar cicilan hutangnya maka barang jaminan dikembalikan (ditarik) oleh pihak perusahaan. Pihak perusahaan memberikan jangka waktu paling lambat tujuh hari setelah penarikan.

Jika pihak konsumen ada I'tikad baik untuk melakukan pembayaran maka pihak perusahaan memberikan kebijakan perpanjangan jangka waktu pelunasan tunggakan. Akan tetapi jika pihak konsumen tidak menunjukkan I'tikad baik sama sekali maka pihak perusahaan berhak melakukan eksekusi terhadap barang jaminan tersebut, dengan cara pihak perusahaan bantu menjual barang jaminan dengan harga pasaran. Hasil penjualan tersebut itu nanti yang akan dibagi oleh perusahaan dengan konsumen, tetapi terkadang hasil penjualan tidak sebanding dengan jumlah tunggakan/hutang konsumen kepada perusahaan.
Dari penjelasan di atas penyelesaian di luar pengadilan didasarkan pada pertimbangan, mengingat jumlah pembiayaan yang diberikan masih relatif kecil, sehingga jika dilihat dari pertimbangan waktu, biaya dan tenaga dirasakan kurang efisien. Selain itu tingkat pendidikan dan pemahaman konsumen yang masih rendah, proses perdamaian dan musyawarah dirasakan lebih memungkinkan dan lebih menguntungkan dalam penyelesaian perselisihan yang terjadi selama ini (Shopie, 2002).

\section{KESIMPULAN}

Praktik murabahah yang dilakukan PT. FIF Syariah pekanbaru dalam rangka memperoleh sepeda motor, baik itu biaya pengiriman, pajak, gaji pegawai, dan sebagainya tidak dimasukkan kedalam biaya perolehan untuk menentukan harga agregat dan margin keuntungan, namun semua biaya-biaya ini sudah ditentukan diawal sebelum adanya akad murabahah. Jika ditinjau berdasarkan hukum islam secara umum syarat-syarat jual beli yang dipraktikkan oleh PT. FIF syariah pekanbaru, maka jual beli murabahah tersebut sudah memenuhi syarat-syarat umum jual beli, namun tidak bisa disebut jual beli murabahah dikarenakan tidak terpenuhinya syarat-syarat khusus jual beli murabahah. Perusahaan pembiayaan syariah ini, sebaiknya harus independen atau berdiri sendiri dan terpisah dari induknya yang masih konvensional. Karena jika masih berada dalam satu atap maka akan sulit rasanya untuk bisa benar-benar menerapkan syariah karena akan terus dibayang-bayangi dan dipengaruhi oleh induknya yang masih konvensional. Harus dilakukan peningkatkan kualitas SDM yang benar-benar paham dan mengerti proses pembiayaan secara syariah, sehingga harapannya agar nanti dapat 
mengembangkan produk syariah dengan baik dan benar tidak hanya mengikuti perintah semat-mata. Meningkatkan sosialisasi produk secara terus menerus, terencana dan terstruktur terhadap semua elemen, baik kepada karyawan, konsumen dan semua pihak yang terlibat didalamnya. Meningkatkan kerjasama dengan mitra, baik koperasi ataupun lainnya yang juga menyalurkan pembiayaan sepeda motor, agar perusahaan dapat memperluas jaringan pemasaran dan dapat meningkatkan citra perusahaan.

\section{DAFTAR PUSTAKA}

Soemitra, Andri. 2009. Bank \& Lembaga Keuangan Syariah. Kencana Prenada Media. Jakarta.

Antonio, Syafi'i. 2003. Bank Syariah dari Teori ke Praktek. Gema Insani Press. Jakarta.

Ega. 2005. Modul Pelatihan FIF Syariah. PT. Federal International Finance.

Handiman, 2006. Bank \& Lembaga Keuangan Bukan Bank. PT. Indeks. Jakarta.

Haryoso, L. 2017. Penerapan Prinsip Pembiayaan Syariah (Murabahah) pada BMT Bina Usaha di Kabupaten Semarang. Law and Justice, 2(1), 79-89

Iltiham, M. F. 2017. Implikasi Akad Simpan Pinjam dalam Perspektif Hukum Kontrak Fiqih (Studi Pada BMT-MMU Pasuruan Cabang Purwosari). MALIA (TERAKREDITASI), 9(1), 83-100.

Maesaroh, N. S. 2017. Implemetasi ganti Rugi Terhadap Keterlambatan Pembayaran Pada Produk Pembiayaan Murabahah di BMT Nurul Ummah Sukabumi. Doctoral
Dissertation. UIN Sunan Gunung Djati. Bandung

Melina, Ficha. 2020. Pembiayaan Murabahah di Baitul Maal wat Tamwil (BMT). Journal of Islamic Banking and Finance, 3(2), 269-280

Melina, Ficha. \& Zulfa, Marina. 2020. Implementasi Pembiayaan Murabahah pada Baitul Maal wat Tamwil (BMT) Kota Pekanbaru. COSTING: Journal of Economic, Business and Accounting, 3(2). 356364.

Muhaimin, 2012. Perusahaan Pembiayaan Syariah di Indonesia. Jurnal Studi Ekonomi, 3(2). 107-122.

Shopie, Yusuf. 2002. Penyelesaian Sengketa Konsumen Menurut Undang-Undang Perlindungan Konsumen atau UUPK, Teori dan Praktek Penegakan Hukum. Citra Aditya Bakti. Mataram.

Suherman, Ade Maman. 2004. Arbitrase dan Alternatif Penyelesaian Sengketa, Aspek Hukum dalam Ekonomi Global. Ghalia Indonesia. Jakarta.

Sunaryo. 2013. Hukum Lembaga Pembiayaan. Cet.3. Sinar Grafika. Jakarta

Suryani, A. \& Afriyeni, A. 2019. Prosedur Pemberian Pembiayaan Murabahah Pada Baitul Mal Wat Tamwil (BMT) Taqwa Muhammadiyah. Padang.

Wiroso, 2005. Jual Beli Murabahah. UII Press. Yogyakarta. 